\title{
Impact of Dry-injection Cultivation to Maintain Soil Physical Properties for an Ultradwarf Bermudagrass Putting Green
}

\author{
Jordan M. Craft, Christian M. Baldwin ${ }^{1}$, Wayne H. Philley, \\ James D. McCurdy, and Barry R. Stewart \\ Department of Plant and Soil Sciences, Mississippi State University, \\ Mississippi State, MS 39762
}

Maria Tomaso-Peterson

Department of Biochemistry, Molecular Biology, Entomology, and Plant Pathology, Mississippi State University, Mississippi State, MS 39762

\author{
Eugene K. Blythe \\ Coastal Research \& Extension Center, Mississippi State University, South \\ Mississippi Branch Experiment Station, Poplarville, MS 39470
}

Additional index words. dry-injection cultivation, bulk density, Cynodon, hollow tine

\begin{abstract}
Traditional hollow-tine (HT) aerification programs can cause substantial damage to the putting green surface resulting in prolonged recovery. Despite the growing interest in new and alternative aerification technology, there is a lack of information in the literature comparing new or alternative technology with traditional methods on ultradwarf bermudagrass [Cynodon dactylon (L.) Pers. $\times$ C. transvaalensis (Burtt-Davy)] putting greens. Therefore, the objective of this research was to determine the best combination of dry-injection (DI) cultivation technology with modified traditional HT aerification programs to achieve minimal surface disruption without a compromise in soil physical properties. Research was conducted at the Mississippi State University golf course practice putting green from 1 June to 31 Aug. 2014 and 2015. Treatments included two HT sizes ( 0.6 and $1.3 \mathrm{~cm}$ diameter), various DI cultivation frequencies applied with a DryJect 4800, and a noncultivated control. The HT $1.3 \mathrm{~cm}$ diameter tine size had $76 \%$ greater water infiltration $(7.6 \mathrm{~cm}$ depth) compared with the DI + HT $0.6 \mathrm{~cm}$ diameter tine size treatment. However, DI + HT $0.6 \mathrm{~cm}$ diameter tine size had greater water infiltration at the $10.1 \mathrm{~cm}$ depth than the noncultivated control. Results suggest a need for an annual HT aerification event due to reduced water infiltration and increased volumetric water content (VWC) in the noncultivated control treatment. It can be concluded that DI would be best used in combination with HT 1.3 or $0.6 \mathrm{~cm}$ diameter tine sizes to improve soil physical properties; however, the DI + HT $0.6 \mathrm{~cm}$ diameter tine size treatment resulted in minimum surface disruption while still improving soil physical properties compared with the noncultivated control.
\end{abstract}

Ultradwarf bermudagrass is the most prevalent warm-season species used on putting greens in warm, humid regions (Hartwiger and O'Brien, 2006). Ultradwarf bermudagrasses have fine-textured leaf blades, short internodes, high shoot density, and the ability to withstand low height of cut, which provides a smooth and fast putting surface (Gray and White, 1999). However, ultradwarf bermudagrasses are rapid thatch producers that quickly generate an excessive thatch-mat layer of organic matter, which negatively affects putting green performance (Carrow, 1998; Fontanier et al., 2011; McCarty et al., 2007; Turgeon, 2005).

Received for publication 9 June 2016. Accepted for publication 11 July 2016.

${ }^{1}$ Corresponding author. E-mail: cmb907@msstate. edu.
The United States Golf Association (USGA) putting green construction method was developed to provide near-ideal soil physical properties that result in an environment conducive for plant growth (Brady and Weil, 1999). The ideal conditions of a USGA putting green diminish over time due to the ability of ultradwarf bermudagrass to generate organic matter (Carrow, 2003). Excessive levels of thatch-mat organic matter causes many problems, including increased ball marks (Vermeulen and Hartwiger, 2005), increased pathogen and insect populations (Bevard, 2005; Christians, 1998), and reduced water infiltration rates (Bevard, 2005).

Hollow-tine aerification, also known as core aerification, is an effective practice that physically removes a soil core to improve soil physical properties. Research has shown that HT aerification improves water infiltration and reduces VWC in putting greens (McCarty et al., 2007; Rowland et al., 2009;
Sorokovsky et al., 2007). Previous research has also suggested that HT aerification combined with verticutting and grooming reduced organic matter concentration more than the untreated control treatment (Atkinson et al., 2012). However, other researchers have reported HT aerification did not reduce organic matter concentration compared with non-HT aerification treatments (McCarty et al., 2007; Rowland et al., 2009; Sorokovsky et al., 2007). Hollow-tine aerification is also used to reduce compaction, which is quantified by measuring bulk density and surface firmness. Increasing the number of HT aerification events has been reported to improve bulk density (Atkinson et al., 2012; Murphy et al., 1993), whereas other researchers have noted no differences in bulk density, which have caused speculation that improvements to bulk density might be short lived (Green et al., 2001; Murphy and Rieke, 1994). As bulk density decreases, soil macroporosity increases, which promotes more efficient air and water movement throughout the soil. Atkinson et al. (2012) noted surface firmness was $4 \%$ lower when impacting $25 \%$ surface area compared with $15 \%$ surface area on a 'TifEagle' bermudagrass putting green. Although traditional HT aerification improves soil physical properties, it can be disruptive to the putting surface resulting in fewer rounds of golf played (Craft, 2016).

Alternative aerification practices, such as spiking, slicing, water-injection (WI) cultivation, and DI cultivation are becoming more popular because they are less disruptive to the putting surface than HT aerification. For example, previous research has shown that WI and spiking can improve water infiltration on sand-based greens with minimal surface disruption (Fontanier et al., 2011; Green et al., 2001; Murphy and Rieke, 1994; Schmid et al., 2014). A considerable amount of previous research has examined traditional aerification timing, depth, and spacing impact on soil physical properties of cool-season grasses (Landreth et al., 2008; McCarty et al., 2007; Murphy et al., 1993; Sorokovsky et al., 2007), while minimal research has concentrated on ultradwarf bermudagrass cultivars.

Determining the best combination of traditional and alternative aerification practices to maintain soil physical properties throughout the growing season while minimizing surface disruption is challenging for turfgrass managers. Despite growing interest in new aerification technology of putting greens, there is a lack of information in the literature comparing new technology with traditional methods - particularly DI. Dry-injection is a process by which high-pressure water injections create holes into the surface with sand and/or other amendments being drawn into the hole by the patented vacuum created by a burst of water (Bigelow and Soldat, 2013; Turgeon, 2012). The objective of this research was to determine the best combination of DI technology with modified traditional HT aerification programs to achieve minimal surface disruption without a compromise in soil physical properties, such as bulk density, VWC, and water infiltration. 


\section{Materials and Methods}

Research was conducted from 1 June to 31 Aug. 2014 and 2015, at the Mississippi State University golf course practice putting green in Starkville, MS $\left(33^{\circ} 28^{\prime} 41^{\prime \prime} \mathrm{N}\right.$, $\left.88^{\circ} 43^{\prime} 58^{\prime \prime} \mathrm{W}\right)$. The practice putting green was constructed in 1994 with a USGA specified, 80:20 (sand:sphagnum peatmoss, v/v) greens soil mixture. In 2004, the green was resprigged with 'MS Supreme' ultradwarf bermudagrass. The Mississippi State University golf course is a public golf course that receives on average 28,000 rounds of golf per year. Plots were $1.5 \times 3.0 \mathrm{~m}$. Mowing occurred $7 \mathrm{~d} \cdot$ week $^{-1}$ at $2.8 \mathrm{~mm}$ using a John Deere 2500B Triplex (Deere and Company, Moline, IL). Fertilizer was applied equally overall plots with urea (46-0-0) and potassium nitrate (13-0-44) together to achieve a rate of $24.4 \mathrm{~kg} \cdot \mathrm{ha}^{-1} \mathrm{~N}$ and $\mathrm{K}$ per month during the growing season. Topdressing was applied with a Dakota 410 pull behind unit (Dakota Peat and Equipment, Grand Fork, ND) during the growing season at a rate of $4.1 \mathrm{~m}^{3} \cdot \mathrm{ha}^{-1} \cdot \mathrm{week}^{-1}$. Irrigation was applied as needed to prevent drought stress, fungicides were applied on a curative basis, and no herbicide applications occurred.

Treatments included two HT sizes (0.6 and $1.3 \mathrm{~cm}$ diameter) and various DI frequencies (Table 1). The HT $0.6 \mathrm{~cm}$ tine size treatments were applied with a John Deere Aerocore 800 (Deere and Company) with $2.5 \mathrm{~cm}$ spacing set to a depth of $7.6 \mathrm{~cm}$. The HT $1.3 \mathrm{~cm}$ tine size treatments were applied with a Toro Procore 648 (The Toro Company, Bloomington, $\mathrm{MN}$ ) with $2.5 \mathrm{~cm}$ spacing set to a depth of $7.6 \mathrm{~cm}$. Cores were removed and plots were sand top-dressed. The DI treatments were applied with a DryJect 4800 (DryJect Incorporated, Hatboro, PA) with $7.6 \mathrm{~cm}$ nozzle spacing set to a $12.6 \mathrm{~cm}$ depth. The DI treatments were injected with AS-45 topdressing sand that met USGA particle size recommendations for a topdressing and root-zone sand mixture according to the Tifton Physical Soil Testing Laboratory (Tifton, GA).

Parameters evaluated included percent visual recovery, chlorophyll index, normalized difference vegetative index (NDVI), ball roll, VWC ( 3.8 and $7.6 \mathrm{~cm}$ depth), surface firmness,

Table 1. Treatments implemented on a 'MS-Supreme' ultradwarf bermudagrass putting green in Starkville, MS, from 1 June to 31 Aug. 2014 and 2015.

\begin{tabular}{lccc}
\hline Treatment & Aerification $^{\mathrm{z}}$ & Tine size $^{\mathrm{y}}$ & Dry-injection $^{\mathrm{x}}$ frequency $^{-}$ \\
\hline Noncultivated control & - & - & - \\
HT 1.3 & HT & 1.3 & - \\
HT 0.6 & HT & 0.6 & - \\
DI 5 & - & - & $5^{\mathrm{w}}$ \\
HT 1.3 + DI 2 & HT & 1.3 & 2 \\
HT 0.6 + DI 5 & HT & 0.6 & 4 \\
HT 0.6 + DI 4 & HT & 0.6 & 2 \\
HT 0.6 + DI 2 & HT & 0.6 &
\end{tabular}

${ }^{\mathrm{z}}$ All aerification (hollow-tine) treatments were applied once a year on 2 July 2014 and 17 July 2015.

${ }^{y}$ The 1.3 and $0.6 \mathrm{~cm}$ treatments were set to a depth of $7.6 \mathrm{~cm}$ with $2.5 \mathrm{~cm}$ spacing.

${ }^{\mathrm{x}}$ Dry-injection nozzles were spaced at $7.6 \mathrm{~cm}$ and set to a $12.6 \mathrm{~cm}$ depth.

${ }^{\mathrm{w}}$ Total number of applications over the 2-year study period. Dry-injection treatments occurred on 3 June 2014, 2 July 2014, 8 Aug. 2014, 6 June 2015, and 17 July 2015. percent soil moisture content. For both depths, measurements were collected 14 and $28 \mathrm{~d}$ after each treatment application. The VWC assessments were collected at three randomly selected locations per plot and averaged to obtain an overall VWC for each depth of reading.

Surface firmness was measured every 14 and $28 \mathrm{~d}$ after each treatment application using a USGA TruFirm Turf Firmness Meter (USGA, Far Hills, NJ). The TruFirm meter measures the maximum penetrating depth of its hemisphere-shaped hammer into the putting green surface. Firmness was measured following a single drop of the hammer in three randomly selected locations of each plot and then averaged to get the overall surface firmness of each individual plot. The results were recorded as depth of penetration $(\mathrm{cm})$ with lower depth values indicating a firmer surface.

Water infiltration rate $\left(\mathrm{cm} \cdot \mathrm{hr}^{-1}\right)(0$ to $7.6 \mathrm{~cm}$ depth) was measured $14 \mathrm{~d}$ after each treatment application with an AMS double-ring infiltrometer (AMS Incorporated, American Falls, ID). Inside and outside ring dimensions had a diameter of 15 and $30 \mathrm{~cm}$, respectively, with a height of $10 \mathrm{~cm}$. Rings were placed once within each plot and inserted $2.0 \mathrm{~cm}$ below the soil surface. Water was added to both rings until the water level reached the top $(8.0 \mathrm{~cm})$ of both rings. Water infiltration was measured as the time it took the water in the center ring to empty from the initial height of $8.0 \mathrm{~cm}$ while maintaining a consistent hydraulic head in the outer ring of the infiltrometer (Gregory et al., 2005). Results were measured after $15 \mathrm{~min}$ and multiplied by four to generate the infiltration rate per hour.

To determine if a pan developed below the tine depth, water infiltration rate $\left(\mathrm{cm} \cdot \mathrm{hr}^{-1}\right)$ (7.6 to $10.1 \mathrm{~cm}$ depth) was measured on 1 Oct. 2015. Water infiltration rate was measured by removing two undisturbed $5.0 \mathrm{~cm}$ diameter soil cores from two randomly selected locations within each plot at a depth of $7.6 \mathrm{~cm}$ using an AMS slide hammer (AMS Incorporated). After the soil core was removed, a $5.0 \mathrm{~cm} \times 15 \mathrm{~cm}$ plastic clear liner was inserted into the hole (where the soil core was removed) and inserted to the $7.6 \mathrm{~cm}$ depth and then pushed $2.0 \mathrm{~cm}$ deeper into the soil profile. Water was added into the cylinder until the water level reached the top $(15 \mathrm{~cm})$ of the cylinder. Water infiltration was measured by observing the time it took the water to empty the cylinder.

Thatch-mat depth (distance from green vegetation to the mat-soil line) was measured by removing two $5.0 \mathrm{~cm}$ diameter soil cores from randomly selected locations from each plot at a depth of $7.6 \mathrm{~cm}$ on 7 Oct. 2014 and 2 Oct. 2015. The soil cores were then dried in a forced air oven for $48 \mathrm{~h}$ at $105{ }^{\circ} \mathrm{C}$ and weighed. After the roots and shoots below the thatch layer were removed, the uncompressed thatch layer depth was measured using a ruler from three points on the soil core, and then, these three points were averaged to determine the overall thatch-mat depth for each plot. Measurements were taken from the top of the turfgrass surface 
to the thatch layer base $(\mathrm{cm})$. Using the method of loss on ignition (LOI; Snyder and Cisar, 2000) to determine organic matter concentration, the soil cores were then placed in a muffle furnace (Blue M Electric Company, Blue Island, IL) for $3 \mathrm{~h}$ at $550{ }^{\circ} \mathrm{C}$. Remaining material was weighed and subtracted from the prefurnace weight to determine organic matter concentration as a percent by weight.

Bulk density $\left(\mathrm{g} \cdot \mathrm{cm}^{-3}\right)$ was measured by removing two undisturbed $5.0 \mathrm{~cm}$ diameter soil cores from two randomly selected locations, from each plot at the depth of $7.6 \mathrm{~cm}$ on 7 Oct. 2014 and 2 Oct. 2015. To lift the cores with turfgrass and root-zone material, an AMS slide hammer was used to insert a stainless steel cylinder into the root zone, and then, the thatch and verdure were removed from the root-zone sample (Blake and Hartge, 1986). Soil cores were then dried in a forced air oven (Precision Science Company, Chicago, IL) for $48 \mathrm{~h}$ at $105^{\circ} \mathrm{C}$. Bulk density was calculated by dividing dry soil core mass by the total soil core volume.

Statistical design and analysis. Treatments were arranged in a randomized complete block design with three replications. Treatment effects were evaluated using analysis of variance with the GLIMMIX procedure in Statistical Analysis System (Version 9.3; SAS Institute Inc., Cary, NC). All tests were performed at a significance level of 0.10 . This level was used to avoid type II errors that could occur due to the inherent variability of soil measurements (Atkinson et al., 2012; Wiecko et al., 1993). All $P$ values for tests of differences between least-squares means were adjusted with the use of the Shaffersimulated method. No year by treatment interaction occurred for any parameter measured; therefore, data collected over the 2-year study were pooled. No significant differences were observed for any data collected in June and August or ball roll at any collection date; therefore, results will not be displayed.

\section{Results and Discussion}

Canopy characteristics. In July, $8 \mathrm{~d}$ after treatment (DAT), HT $1.3+$ DI 2 and HT 1.3 had the lowest percent recovery compared with HT 0.6 , DI 5, and the noncultivated control (Table 2). Hollow-tine 1.3 recovered to $90 \%$ while HT 0.6 and DI 5 recovered to $\approx 99 \%$ at 15 DAT. Overall, HT 1.3 and HT $1.3+$ DI 2 had the slowest percent recovery compared with DI and HT 0.6 treatments. Incorporating DI with HT did not reduce or increase recovery. DI and HT 0.6 treatments had similar percent recovery. This likely occurred due to the surface area impacted by each treatment. Hollow-tine 1.3, HT 0.6, and DI impacted $19.6 \%, 4.9 \%$, and $<1 \%$ surface area, respectively. Landreth et al. (2008) stated that tine diameter had the greatest effect on recovery time. With that being said, DI and HT 0.6 treatments similar recovery time can likely be attributed to a similar diameter of hole created on the surface.
In July, 14 DAT, HT 1.3 and HT $1.3+$ DI 2 had a $\approx 7 \%$ lower chlorophyll index compared with the noncultivated control (Table 2). This supports the percent recovery data as HT 1.3 and HT 1.3 + DI 2 had a lower percent recovery at this date compared with the noncultivated control. Also, chlorophyll index results were similar to percent recovery as the addition of DI into a HT treatment did not increase or decrease chlorophyll index. No chlorophyll index differences were observed at 28 DAT, which can likely be attributed to all plots being fully recovered at this time.

Volumetric water content. At $3.8 \mathrm{~cm}$ depth, 14 DAT in July, HT 1.3 had $\approx 11 \%$ lower VWC compared with the noncultivated control and HT 0.6 (Table 3). The noncultivated control, with the exception of HT 0.6 , had the highest VWC compared with all treatments. All DI treatments had a significantly lower VWC than the noncultivated control. Incorporating DI into the HT 1.3 treatment did not increase or decrease VWC. However, incorporating DI into the HT 0.6 treatment, regardless of DI frequency, lowered VWC at $\approx 10 \%$. This likely occurred for the HT 0.6 treatment because the DI process creates a subsurface fracture while creating a $0.6 \mathrm{~cm}$ surface hole; however, as the material goes into the root-zone profile, it expands creating a sand column that extends to a $12.6 \mathrm{~cm}$ depth. By 28 DAT, a reduction of VWC was not observed with the addition of DI into a HT treatment. Meanwhile, the noncultivated control had $\approx 11 \%$ higher VWC compared with the HT 1.3 and DI 5 treatments.

At the $7.6 \mathrm{~cm}$ depth, 14 DAT in July, similar results were observed at the $3.8 \mathrm{~cm}$ depth (Table 3). The noncultivated control had the highest VWC compared with HT 1.3, HT $1.3+$ DI 2 , and HT 0.6 + DI 2 treatments. Frequency of DI events did not significantly affect VWC at 14 or 28 DAT. Similarly,

Table 2. Percent recovery and chlorophyll index in July on a 'MS-Supreme' ultradwarf bermudagrass putting green following various aerification and dry-injection cultivation treatments in Starkville, MS, from 1 June to 31 Aug. 2014 and 2015.

\begin{tabular}{|c|c|c|c|c|c|c|}
\hline \multirow[b]{3}{*}{ Treatment ${ }^{\mathrm{x}}$} & \multicolumn{4}{|c|}{ Recovery $\% \mathrm{z}$} & \multirow{2}{*}{\multicolumn{2}{|c|}{$\frac{\text { Chlorophyll index }^{\mathrm{y}}}{(0-900)}$}} \\
\hline & \multicolumn{4}{|c|}{$(0-100)$} & & \\
\hline & $5 \mathrm{DAT}^{\mathrm{w}}$ & $8 \mathrm{DAT}$ & $12 \mathrm{DAT}$ & $15 \mathrm{DAT}$ & $14 \mathrm{DAT}$ & $28 \mathrm{DAT}$ \\
\hline Noncultivated control & $100 \mathrm{a}^{\mathrm{v}}$ & $100 \mathrm{a}$ & $100 \mathrm{a}$ & $100 \mathrm{a}$ & $284 \mathrm{a}$ & 300 \\
\hline HT 1.3 & $50 \mathrm{c}$ & $67 \mathrm{~cd}$ & $83 \mathrm{~cd}$ & $90 \mathrm{~b}$ & $263 \mathrm{~b}$ & 282 \\
\hline HT 0.6 & $70 \mathrm{~b}$ & $82 \mathrm{~b}$ & $93 \mathrm{ab}$ & 99 a & $274 \mathrm{ab}$ & 301 \\
\hline DI $5^{\mathrm{u}}$ & $73 \mathrm{~b}$ & $83 \mathrm{~b}$ & $96 \mathrm{ab}$ & $98 \mathrm{a}$ & $273 \mathrm{ab}$ & 292 \\
\hline HT $1.3+$ DI 2 & $45 \mathrm{c}$ & $62 \mathrm{~d}$ & $80 \mathrm{~d}$ & $91 \mathrm{~b}$ & $267 \mathrm{~b}$ & 284 \\
\hline HT 0.6 + DI 5 & $70 \mathrm{~b}$ & $78 \mathrm{bc}$ & $92 \mathrm{ab}$ & $97 \mathrm{a}$ & $275 \mathrm{ab}$ & 297 \\
\hline HT $0.6+$ DI 4 & $69 \mathrm{~b}$ & $75 \mathrm{bcd}$ & $90 \mathrm{bc}$ & $100 \mathrm{a}$ & $270 \mathrm{ab}$ & 286 \\
\hline HT $0.6+$ DI 2 & $67 \mathrm{~b}$ & $77 \mathrm{bc}$ & $89 \mathrm{bc}$ & $96 \mathrm{a}$ & $270 \mathrm{ab}$ & 284 \\
\hline
\end{tabular}

${ }^{\mathrm{z}} \mathrm{A} 0 \%$ to $100 \%$ linear scale was used to estimate recovery where $100 \%=$ full coverage.

${ }^{\mathrm{y}}$ Three readings were taken in randomly selected locations per plot, which were then averaged to get an overall chlorophyll index of each plot.

${ }^{\mathrm{x}} \mathrm{HT}=$ hollow tine; $\mathrm{DI}=$ dry injection; $1.3=1.3 \mathrm{~cm}$ diameter tine; $0.6=0.6 \mathrm{~cm}$ diameter tine.

${ }^{\mathrm{w}} \mathrm{DAT}=$ days after treatment

${ }^{v}$ Means within each column followed by the same letter are not significantly different according to the Shaffer-simulated test $(P \leq 0.10)$.

"Values following DI represent the number of dry-injection applications over the 2-year study period. Dryinjection applications occurred on 3 June 2014, 2 July 2014, 8 Aug. 2014, 6 June 2015, and 17 July 2015.

Table 3. Volumetric water content (3.8 and $7.6 \mathrm{~cm}$ depths) and surface firmness ( $\mathrm{cm}$ ) collected in July on an 'MS-Supreme' ultradwarf bermudagrass putting green following various aerification and dryinjection cultivation treatments in Starkville, MS, from 1 June to 31 Aug. 2014 and 2015.

\begin{tabular}{|c|c|c|c|c|c|c|}
\hline \multirow[b]{4}{*}{ Treatment $^{\mathrm{x}}$} & \multicolumn{4}{|c|}{ Volumetric water content } & & \\
\hline & \multicolumn{4}{|c|}{$(\%)$} & & \\
\hline & \multicolumn{2}{|c|}{$3.8 \mathrm{~cm} \mathrm{depth}^{2}$} & \multicolumn{2}{|c|}{$7.6 \mathrm{~cm}$ depth } & \multicolumn{2}{|c|}{ Surface firmness ${ }^{\mathrm{y}}(\mathrm{cm})$} \\
\hline & $14 \mathrm{DAT}^{\mathrm{w}}$ & $28 \mathrm{DAT}$ & $14 \mathrm{DAT}$ & $28 \mathrm{DAT}$ & 14 DAT & $28 \mathrm{DAT}$ \\
\hline Noncultivated control & $25.2 \mathrm{a}^{\mathrm{v}}$ & $24.7 \mathrm{a}$ & $30.2 \mathrm{a}$ & $29.6 \mathrm{a}$ & 1.14 & $1.13 \mathrm{~b}$ \\
\hline HT 1.3 & $22.6 \mathrm{c}$ & $22.1 \mathrm{c}$ & $27.0 \mathrm{bc}$ & $27.2 \mathrm{bcd}$ & 1.21 & $1.25 \mathrm{a}$ \\
\hline HT 0.6 & $24.8 \mathrm{ab}$ & $24.6 \mathrm{ab}$ & $28.6 \mathrm{ab}$ & $29.2 \mathrm{ab}$ & 1.21 & $1.17 \mathrm{ab}$ \\
\hline DI $5^{u}$ & $23.3 \mathrm{bc}$ & $22.6 \mathrm{bc}$ & $27.7 \mathrm{abc}$ & $28.0 \mathrm{abc}$ & 1.18 & $1.16 \mathrm{ab}$ \\
\hline HT $1.3+$ DI 2 & $23.3 \mathrm{bc}$ & $22.8 \mathrm{abc}$ & $26.3 \mathrm{bc}$ & $26.8 \mathrm{~cd}$ & 1.17 & $1.20 \mathrm{ab}$ \\
\hline HT $0.6+$ DI 5 & $22.7 \mathrm{c}$ & $22.8 \mathrm{abc}$ & $24.5 \mathrm{a}-\mathrm{c}$ & $26.9 \mathrm{~cd}$ & 1.23 & $1.20 \mathrm{ab}$ \\
\hline HT $0.6+$ DI 4 & $22.3 \mathrm{c}$ & $22.9 \mathrm{abc}$ & $26.7 \mathrm{bc}$ & $27.0 \mathrm{bcd}$ & 1.18 & $1.15 \mathrm{ab}$ \\
\hline HT $0.6+$ DI 2 & $22.3 \mathrm{c}$ & $22.9 \mathrm{abc}$ & $25.2 \mathrm{c}$ & $24.9 \mathrm{~d}$ & 1.17 & $1.20 \mathrm{ab}$ \\
\hline
\end{tabular}

${ }^{\mathrm{z}}$ Depth of reading.

yFirmness was measured following a single drop of the hammer in three randomly selected locations of each plot and then averaged to get the overall surface firmness of each individual plot.

${ }^{\mathrm{x}} \mathrm{HT}=$ hollow tine; $\mathrm{DI}=$ dry injection; $1.3=1.3 \mathrm{~cm}$ diameter tine; $0.6=0.6 \mathrm{~cm}$ diameter tine.

${ }^{\mathrm{w}} \mathrm{DAT}=$ days after treatment.

${ }^{v}$ Means within each column followed by the same letter are not significantly different according to the Shaffer-simulated test $(P \leq 0.10)$.

"Values following DI represent the number of dry-injection applications over the 2-year study period. Dryinjection treatments occurred on 3 June 2014, 2 July 2014, 8 Aug. 2014, 6 June 2015, and 17 July 2015. 
incorporating DI into the HT 0.6 and 1.3 treatments did not impact VWC. At 28 DAT, HT 1.3 had a $9 \%$ reduction in VWC, while all HT treatments combined with DI had $\approx 12 \%$ lower VWC compared with the noncultivated control.

At both depths measured, HT 1.3 was the most effective management practice that consistently reduced VWC. Sorokovsky et al. (2007) observed a similar trend where a HT aerification resulted in a lower VWC than the non-HT aerification treatment. Similarly, Rowland et al. (2009) found that HT aerification reduced VWC compared with verticutting plots on an ultradwarf bermudagrass putting green.

Surface firmness. At 28 DAT in July, HT 1.3 had an $11 \%$ softer surface compared with the noncultivated control (Table 3 ). This is most likely due to HT 1.3 impacting the largest percentage of surface area; however, HT 1.3 + DI 2 did not have a significantly softer surface, which could be a product of the DI treatment applied after the HT 1.3 treatment. The DI treatment applied following HT 1.3 may have partially filled some aerification holes with sand resulting in an increase in soil strength, which caused the surface to be firmer.

Several studies have evaluated HT aerification impact on surface firmness and found similar results as reported in this study. McCarty et al. (2007) and Murphy et al. (1993) reported that a creeping bentgrass (Agrostis stolonifera L.) putting green treated with HT aerification had reduced surface firmness compared with solid tine (ST) aerification. Atkinson et al. (2012) noted surface firmness was $4 \%$ lower when impacting $25 \%$ compared with $15 \%$ surface area on an ultradwarf bermudagrass putting green.

Water infiltration. At 14 DAT in July, HT 1.3 had a $76 \%$ higher infiltration rate than the HT 0.6 + DI 5 treatment (Table 4). Previous research has also reported that HT aerification provides greater infiltration rates compared with the noncultivated control treatment (Schmid et al., 2014; Sorokovsky et al., 2007). The highest infiltration rate noted for the HT 1.3 treatment may be due to percent surface area impacted and the physical removal of a soil core. Sorokovsky et al. (2007) also observed after 2 years that WI applied with a (The Toro Co., Minneapolis, MN) produced a significantly higher infiltration rate than all other treatments with the exception of HT aerification treatments. The HydroJect uses the same fracture technique as DI with the exception that HydroJect does not have the ability to inject sand into the holes created. Green et al. (2001) observed a similar trend as infiltration rates increased in plots that received WI and ST aerification treatments compared with the control. Also, Green et al. (2001) noted that HydroJect in the raised position compared with the lowered position created the largest hole, which caused the hole to remain open for a longer period resulting in increased infiltration rates.

Brauen et al. (1998) speculated that over a period of time, HT aerification may

Table 4. Water infiltration $\left(\mathrm{cm} \cdot \mathrm{hr}^{-1}\right)$ rates at two depths on a 'MS Supreme' ultradwarf bermudagrass putting green as affected by various core aerification and dry-injection treatments in Starkville, MS, from 1 June to 31 Aug. 2014 and 2015.

\begin{tabular}{|c|c|c|}
\hline \multirow[b]{3}{*}{ Treatment $^{\mathrm{z}}$} & 0 to $7.6 \mathrm{~cm} \mathrm{depth}$ & 7.6 to $10.1 \mathrm{~cm}$ depth \\
\hline & $14 \mathrm{DAT}^{\mathrm{y}}$ & 1 Oct. 2015 \\
\hline & \multicolumn{2}{|c|}{$\mathrm{cm} \cdot \mathrm{hr}^{-1}$} \\
\hline Noncultivated control & $6.50 b^{x}$ & $144 \mathrm{~b}$ \\
\hline HT 1.3 & $25.83 \mathrm{a}$ & $196 \mathrm{ab}$ \\
\hline HТ 0.6 & $14.10 \mathrm{ab}$ & $171 \mathrm{ab}$ \\
\hline DI $5^{\mathrm{w}}$ & $12.66 \mathrm{ab}$ & $211 \mathrm{ab}$ \\
\hline HT 1.3 + DI 2 & $19.80 \mathrm{ab}$ & $192 \mathrm{ab}$ \\
\hline HT $0.6+$ DI 5 & $11.60 \mathrm{~b}$ & $178 \mathrm{ab}$ \\
\hline HT $0.6+$ DI 4 & $13.80 \mathrm{ab}$ & $260 \mathrm{a}$ \\
\hline HT 0.6 + DI 2 & $16.60 \mathrm{ab}$ & $264 \mathrm{a}$ \\
\hline
\end{tabular}

${ }^{\mathrm{z}} \mathrm{HT}=$ hollow tine; $\mathrm{DI}=$ dry injection; $1.3=1.3 \mathrm{~cm}$ tine diameter; $0.6=0.6 \mathrm{~cm}$ tine diameter.

${ }^{\mathrm{y}} \mathrm{DAT}=$ days after treatment.

${ }^{\mathrm{x}}$ Means within each column followed by the same letter are not significantly different according to the Shaffer-simulated test $(P \leq 0.10)$.

${ }^{\text {w}}$ Values following DI represent the number of dry-injection applications over the 2-year study period. Dryinjection applications occurred on 3 June 2014, 2 July 2014, 8 Aug. 2014, 6 June 2015, and 17 July 2015.

develop a compaction layer below the tine depth penetration zone. The HT aerification treatments penetration depth was $7.6 \mathrm{~cm}$, while DI treatments was $12.6 \mathrm{~cm}$. The DI technique creates an aerification hole by injecting water into the ground just as the WI does; however, DI fills the holes with sand created by the highpressure water injection. At the end of the study, infiltration was measured at the 7.6 to $10.1 \mathrm{~cm}$ depth to better understand the fracturing technique and its influence on water infiltration deeper within the soil profile. At this depth, HT $0.6+$ DI 4 and HT 0.6 + DI 2 treatments had a significantly higher infiltration rate than the noncultivated control (Table 4). However, incorporating DI into a HT 0.6 or HT 1.3 treatment did not increase water infiltration compared with single HT 0.6 and HT 1.3 treatments. The results did not indicate a compaction zone below the HT depth, but it did confirm the importance of an aerification event since the noncultivated control had a significantly lower infiltration rate. Future research is needed to further understand the DI fracturing technique and its impact on water infiltration deeper into the root zone.

Thatch-mat depth and organic matter concentration. Differences in thatch-mat depth were not observed (average 33-mm depth) between treatments. Similarly, McCarty et al. (2007) did not detect differences after four HT aerification treatments. No differences in thatch-mat depth at the conclusion of this study may be attributed to soil sample size (diameter) and the number of samples collected per plot. Carrow et al. (1987) speculated that an accurate thatch-mat depth determination may be difficult to determine as cultivation practices mix sand or soil into the thatch-mat layer.

Similar to thatch-mat depth, differences in organic matter concentration between treatments (average 5\%) were not observed. Similarly, Schmid et al. (2014) reported after 2 years that HT aerification, ST aerification, and venting were not effective at reducing organic matter concentrations on two creeping bentgrass putting green cultivars. Sorokovsky et al. (2007) and Rowland et al. (2009) also reported HT aerification did not reduce organic matter concentration compared with non-HT aerification treatments. Atkinson et al. (2012) found that as the number of HT aerification events per year increased from one to three, organic matter concentration was reduced. McCarty et al. (2007) found that HT aerification combined with verticutting and grooming reduced organic matter concentration more than the untreated control.

Bulk density. Differences in bulk density between treatments were not observed. The impact of aerification practices on bulk density varies throughout the literature. For example, Green et al. (2001) did not observe significant changes in bulk density following ST aerification and WI treatments on an annual bluegrass (Poa annua L.) putting green. However, Murphy and Rieke (1994) found that WI and HT aerification significantly lowered bulk density values. Atkinson et al. (2012) reported as the number of HT aerification events increased per year, bulk density was reduced by $5 \%$ compared with one aerification event per year. Researchers have observed and speculated the improvements of bulk density might be short lived or difficult to obtain consistent results (Lee, 1989; Murphy and Rieke, 1994; Roberts, 1975). It is possible bulk density differences would have occurred if more samples per plot were collected. Also, Green et al. (2001) speculated a long-term study would be required to sufficiently modify the existing soil texture that would result in bulk density differences.

\section{Conclusion}

Results indicate HT 1.3 was the most effective treatment at increasing water infiltration and reducing VWC. Although the HT 1.3 treatment was effective at improving soil physical properties, it also had the slowest percent recovery. The HT 0.6 and DI treatments caused minimum disruption to the putting green surface; however, they did not provide the same improvements to the soil physical properties as the HT 1.3 treatment. The DI treatments improved soil physical properties compared with the noncultivated control. It can be concluded that DI would 
be best used in combination with HT 1.3 or HT 0.6 to improve soil physical properties; however, DI + HT 0.6 would be the best combination as minimum surface disruption occurred, while improved soil physical properties were observed. Results suggest a need for an annual HT aerification event due to reduced water infiltration and increased VWC in the noncultivated control treatment. A long-term research study is needed to better understand the effects of DI on soil physical properties, and research should be initiated to optimize spacing, depth, timing, and effects of increased DI frequency. Further research should examine bulk density, organic matter concentration, and water infiltration in the 7.6 to $12.6 \mathrm{~cm}$ depth since DI injects material into this part of the soil profile.

\section{Literature Cited}

Atkinson, J.L., L.B. McCarty, and W.C. Bridges. 2012. Effect of core aerification frequency, area impacted, and topdressing rate on turf quality and soil physical properties. Agron. J. 104:1710-1715.

Bevard, D.S. 2005. Basic Training. USGA Green Section Record. 43:1-6.

Bigelow, C.A. and D.J. Soldat. 2013. Turfgrass root zones: Management, construction methods, amendment characterization, and use, p. 390393. In: J.C. Stier, B.P. Horgan, and S.A. Bonos (eds.). Turfgrass: Biology, use, and management. Agron. Monogra. 56. ASA, CSSA, SSSA, Madison WI.

Blake, G.R. and K.H. Hartge. 1986. Bulk density, p. 363-375. In: A. Klute (ed.). Methods of soil analysis. Part 1.2nd ed. SSSA Book Ser. 5. ASA and SSSA, Madison, WI.

Brady, N.C. and R.R. Weil. 1999. The nature and properties of soils. Prentice Hall, Upper Saddle River, NJ.

Brauen, S.E., W.J. Johnston, and R.L. Goss. 1998. Long-term aerification: A bentgrass fairway study compares hollow- and solid-tine core aerification. USGA Green Section Record. 36:13-15.

Carrow, R. N. 2003. Surface organic matter in bentgrass greens. USGA Turfgrass Environmental research online 2:1-12.
Carrow, R.N., B.J. Johnson, and R.E. Burns. 1987. Thatch and quality of Tifway bermudagrass turf in relation to fertility and cultivation. Agron. J. 79:524-530.

Carrow, R.N. 1998. Organic matter dynamics in the surface zone of a USGA green: Practice to alleviate problems. The USGA 1998 Turfgrass and environmental Research Summary. Golf House, Far Hills, NY.

Christians, N.E. 1998. Fundamentals of turfgrass management. Ann Arbor Press, Chelsea, MI Greens Section, Far Hills, NJ.

Craft, J.M. 2016. Maintaining soil physical property integrity in turfgrass management systems. MS thesis, Mississippi State University, Starkville, MS.

Fontanier, C.H., K. Steinke, J.C. Thomas, and R.H. White. 2011. Effects of venting aeration on neglected bermudagrass putting greens. Online. Appl. Turfgrass Sci., doi:10.1094/ATS 20111201-01-RS.

Gaussoin, R., J. Nusand, and L. Leuthold. 1995. A modified stimpmeter for small-plot turfgrass research. HortScience 30:547-548.

Gitelson, A.A., Y. Gritz, and M.N. Merzlyak. 2003. Relationships between leaf chlorophyll content and spectral reflectance and algorithms for nondestructive chlorophyll assessment in higher plant leaves. J. Plant Physiol. 160:271-282.

Gray, J.L. and R.H. White. 1999. Maintaining the new dwarf greens-type bermudagrasses. Golf Course Mgt. 67:52-55.

Gregory, J.H., M.D. Dukes, G.L. Miller, and P.H. Jones. 2005. Analysis of double ring infiltration techniques and development of a simple automatic water delivery system. Applied Turfgrass Sci. doi:10.1094/ATS-2005-0531-01-MG.

Green, R.L., G.J. Klein, and L. Wu. 2001. Summer cultivation increases field infiltration rates of water and reduces soil electrical conductivity on annual bluegrass golf greens. HortScience 36:776-779.

Hartwiger, C. and P. O'Brien. 2006. The ultradwarf invasion. Carolinas Golf Course Superintendents Assoc., Liberty, SC.

Landreth, J., D. Karcher, and M. Richardson. 2008. Cultivating to manage organic matter in sandbased putting greens: University of Arkansas researchers provide important insight for managing organic buildup on putting greens. USGA Green Section Record 46:16-19.
Lee, D.K. 1989. Effects of soil cultivation techniques on rooting of Kentucky bluegrass sod. MS thesis, Ohio State Univ., Columbus, $\mathrm{OH}$.

Mangiafico, S.S. and K. Guillard. 2007. Coolseason turfgrass color and growth calibrated to leaf nitrogen. Crop Sci. 47:1217-1224.

McCarty, L.B., M.F. Gregg, and J.E. Toler. 2007. Thatch and mat management in an established creeping bentgrass golf green. Agron. J. 99: 1530-1537.

Murphy, J.A., P.E. Rieke, and A.E. Erickson. 1993. Core cultivation of a putting green with hollow and solid-tines. Agron. J. 85:1-9.

Murphy, J.A. and P.E. Rieke. 1994. High pressure water and core cultivation of a compacted putting green. Agron. J. 86:719-724.

Roberts, J.M. 1975. Some influences of cultivation on the soil and turfgrass. MS thesis, Purdue Univ., West Lafayette, IN.

Rowland, J.H., J.L. Cisar, G.H. Synder, J.B. Sartain, and A.L. Wright. 2009. USGA ultradwarf bermudagrass putting green properties as affected by cultural practices. Agron. J. 101:1565-1572.

Schmid, C.J., R.E. Gaussoin, R.C. Shearman, M. Mamo, and C.S. Wortmann. 2014. Cultivation effects on organic matter concentration and infiltration rates of two creeping bentgrass (L.) putting greens. Applied Turfgrass Sci. 11:1-7.

Snyder, G.H. and J.L. Cisar. 2000. Nitrogen/ potassium fertilization ratios for bermudagrass turf. Crop Sci. 40:1719-1723.

Sorokovsky, P., M. Krzic, and M.D. Novak. 2007. Core aeration of sand-based putting Greens in the Lower Fraser Valley of British Columbia. Can. J. Soil Sci. 87:103-111.

Turgeon, A.J. 2005. Turfgrass management. 7th ed. Pearson Prentice Hall, Upper Saddle River, NJ. Turgeon, A.J. 2012. Turfgrass management. 9th ed. Pearson Prentice Hall, Upper Saddle River, NJ.

Vermeulen, P. and C. Hartwiger. 2005. Strategies for organic matter control. USGA Green Section Record 33:1-5.

Wiecko, G., R.N. Carrow, and K.J. Karnok. 1993. Turfgrass cultivation methods: Influence on soil physical, root/shoot, and water relationships. Intl. Turfgrass Soc. Res. J. 7:451-457. 